\title{
Improving the efficacy of extended storage for reducing the risk of viral contaminated plant-based feed ingredients through investigating ambient temperature requirements.
}

\author{
Nicholas Dee ${ }^{1}$, Karyn A. Havas², Apoorva Shah ${ }^{3}$, Aaron Singrey ${ }^{4}$, Gordon Spronk ${ }^{2}$, Megan \\ Niederwerder $^{5}$, Eric Nelson ${ }^{4}$, and Scott Dee ${ }^{2}$ \\ ${ }^{1}$ University of Minnesota School of Public Health \\ ${ }^{2}$ Pipestone County \\ ${ }^{3}$ Eden Prairie Schools \\ ${ }^{4}$ South Dakota State University Department of Veterinary and Biomedical Sciences \\ ${ }^{5}$ Kansas State University College of Veterinary Medicine
}

February 8, 2022

\begin{abstract}
Viruses of veterinary significance such as African swine fever virus, are known to survive for extended periods in plant-based feed ingredients imported into North America. To reduce the likelihood of virus introduction, high-risk ingredients, such as oil seed meals, are stored in designated facilities for extended periods under controlled environmental conditions to minimize viral infectivity prior to use in diets. While 30 days has become a standard storage period, the required ambient temperature to inactivate viruses during this time is not known. To address the question, 1-metric ton totes of conventional soybean meal were inoculated with PRRSV 144 lineage $1 \mathrm{C}$ variant and SVA prior to storage for 30 days at $23.9^{\circ} \mathrm{C}, 15.5^{\underline{0}} \mathrm{C}$, or $10^{\circ} \mathrm{C}$, and feeding to pigs. Virus infectivity was evaluated through detection of viral RNA in oral fluid samples, along with clinical signs. Results indicated that inactivation of both viruses occurred in soy stored at $23.9^{\circ} \mathrm{C}$. In contrast, SVA infectivity was observed in soy stored at both $15.5^{\circ} \mathrm{C}$ and $10^{\circ} \mathrm{C}$, while PRRSV $144 \mathrm{~L} 1 \mathrm{C}$ variant infectivity was only observed in soy stored at $10^{\circ} \mathrm{C}$. These results suggest that a storage period of 30-days and a temperature of $23.9^{\mathrm{O}} \mathrm{C}$ are required to reduce the risk of virus contaminated plant-based feed ingredients, such as soybean meal.
\end{abstract}

\section{Hosted file}

Dee S, Extended storage FINAL.docx available at https://authorea.com/users/459563/articles/ 555788-improving-the-efficacy-of-extended-storage-for-reducing-the-risk-of-viralcontaminated-plant-based-feed-ingredients-through-investigating-ambient-temperaturerequirements 